\title{
Cosmopolitan Democratic and Communicative Rights: The Danish Cartoons Controversy and the Right to Be Heard, Even Across Borders
}

\author{
Alexander Brown ${ }^{1}\left[\right.$ [ $\cdot$ Sune Lægaard ${ }^{2}$ \\ Published online: 15 October 2020 \\ (C) The Author(s) 2020
}

\begin{abstract}
During the Danish cartoons controversy in 2005-2006, a group of ambassadors to Denmark representing eleven predominantly Muslim countries requested a meeting with the Danish Prime Minister, Anders Fogh Rasmussen, to protest against the cartoons. Rasmussen interpreted their viewpoint as one of demanding limits to freedom of speech and he ignored their request for a meeting. Drawing on this case study, the article argues that it is an appropriate, and potentially effective, moral criticism of anyone who is in a position of political power-taking into account reasonable constraints of feasibility and practicality - that they have refused to receive information, ideas, or opinions from individuals, or their representatives, with dissenting viewpoints. The article also articulates one possible theoretical ground for such a moral criticism: that they could be violating a fundamental (cosmopolitan) moral right of people to submit information, ideas, or opinions to those who wield power over them and to be meaningfully heard - a right which can span state borders.
\end{abstract}

Keywords Cosmopolitanism - Danish cartoons controversy · Democracy · Diplomacy . Free speech $\cdot$ Human rights $\cdot$ Political communication $\cdot$ Right to petition $\cdot$ Right to be heard

Alexander Brown

alexander.c.brown@uea.ac.uk

Sune Lægaard

laegaard@ruc.dk

1 School of Politics, Philosophy, Language and Communication Studies, University of East Anglia (UEA), Norwich Research Park, Norwich, Norfolk NR4 7JU, UK

2 Department of Communication and Arts, Roskilde University, Universitetsvej 1, 42.3, DK-4000 Roskilde, Denmark 


\section{Introduction}

During the Danish cartoons controversy in 2005-2006, a group of ambassadors to Denmark representing eleven predominantly Muslim countries requested a meeting with the Danish Prime Minister, Anders Fogh Rasmussen, to protest against the cartoons. Rasmussen interpreted their viewpoint as one of demanding limits to freedom of speech and he ignored their request for a meeting. As justification, he proffered the principled reason that what they apparently wished to question him about - the idea that freedom of speech has such special importance in Danish society that it warrants the protection of even the publication of cartoons which are harmful to Muslims - was beyond questioning. Rasmussen's choice to refuse to meet with the ambassadors in person to hear their views in full (or at length) on grounds of the special importance of freedom of speech might seem to involve a form of paradox, double-thinking, or hypocrisy. If free speech is of special importance, is this not also the case when the speech concerns the question of the limits of freedom of speech itself?

This article takes as its starting point an intuition that, we believe, some people may have had about Rasmussen's choice. Whilst recognizing that Rasmussen did hear the ambassadors' initial grievance (by reading the letter submitted to him) and did provide one means of submitting information to him (by receiving the letter submitted to him), there was something nevertheless morally problematic about his decision to refuse to meet the ambassadors in person to hear their concerns in full (or at length).

Based on this, we consider one possible way of making sense of this intuition - a way that departs from the simple idea that it involved a paradox of free speech. This way involves combining aspects of cosmopolitan political theory, deliberative approaches to democratic theory, diplomatic communication theory, and discourse theory. In particular, we draw on the deliberative, diplomatic and discursive virtues of openness, inclusiveness, equality or parity, translation, and access, which we extend to contexts of international political interaction and communication. We argue that, ultimately, Rasmussen's choice may have involved the partial violation of a fundamental (cosmopolitan) moral right: the right to submit information, ideas, and opinions to those who wield power over oneself, even across borders, and to be meaningfully heard.

The remainder of the article unfolds like this. The next section describes in more detail the nature and context of Rasmussen's choice and articulates more fully the charge that Rasmussen's choice not to engage in direct or face-to-face talks with the ambassadors on grounds of the special importance of freedom of speech was in effect a denial of the very grounds being offered for refusing to speak.

Following on from that, and in order to lay the conceptual groundwork for our own moral diagnosis of Rasmussen's choice, we briefly outline some insights from cosmopolitan political theory, deliberative approaches to democratic theory, diplomatic communication theory, and discourse theory.

We then make the argument that Rasmussen partially violated a fundamental (cosmopolitan) moral right to be meaningfully heard on the part of those Muslims adversely affected by the cartoons, including Muslims living in other countries. In this article, we do not have space to provide a full theory of what such a right would involve. Rather, our claim is that such a right can account for the initial intuition. This opens up a broader research agenda in diplomatic ethics as well in cosmopolitan deliberative and communicative rights, which we can only begin in this article. 
In the final section, we explore more recent developments in the Danish cartoons controversy and then consider the implications of conventional practices of international diplomacy for our arguments about the right to be meaningfully heard.

\section{Rasmussen's Choice}

Restrictive policies regarding immigration had been the winning card for the Danish centre-right government headed since 2001 by Prime Minister Rasmussen. The policies were also important in maintaining the parliamentary support of the Danish People's Party (Lægaard 2013: 176-184). Simultaneously, immigration was increasingly understood within Danish society as being about Muslims and was seen in the frame of the war against terror (ibid).

In this context, a more general critical tone against strands of Islam perceived as obstacles to integration had become mainstream in Denmark.

Jyllands-Posten is one of the largest national newspapers in Denmark. It had long been the main outlet for critical views of Islam in Denmark and strongly backed the Rasmussen government's line on immigration in general and on political correctness in particular.

During the summer of 2005 , stories ran in the Danish media involving apparent political correctness towards Muslims and Islam. One featured a children's books author, Kåre Bluitgen, who wanted to publish a children's book about the prophet Muhammad. Bluitgen was both a left-wing proponent of multiculturalism and a critic of some of the shadier sides of the Danish multicultural reality, including lack of contact between most Danes and Muslims and repressive aspects of Muslim communities. The story was that Bluitgen had not been able to find an illustrator for the book.

The editorial team of Jyllands-Posten picked up on this and other stories apparently showing anxiety about offending Muslims. The newspaper decided to run what was supposed to be a kind of experiment testing the degree of self-censorship among political cartoonists, a statement supporting free speech, and a deliberate attempt to take a stand against political correctness. Culture Editor Fleming Rose got the job of soliciting the cartoons as well as writing the accompanying text. A former correspondent to Moscow, Rose viewed free speech as a cornerstone of liberal democracy and self-censorship as the hallmark of a totalitarian society.

The twelve cartoons, which resulted, were printed on 30 September 2005 together with Rose's text. According to Rose, there are increasing pressures towards selfcensorship in Western societies, especially when it comes to questions about Islam and Muslims, some of whom demand special treatment and consideration of their religious sensibilities. He continued:

This is incompatible with a secular democracy and free speech, where one must be ready to put up with ridicule, mockery and derision. (Rose 2005, authors' translation)

In the present article, we will not cover the entire train of events that unfolded following the publication of the cartoons. We will focus on one specific incident that took place shortly after the publication, but which came to epitomize the principled disagreements at the centre of the Danish cartoons controversy. 
Shortly after the publication, the Egyptian Government, which was facing the Muslim Brotherhood in an upcoming general election and arguably needed a way of presenting itself as a true protector of Islam, initiated a diplomatic offensive against Denmark (Klausen 2009, ch 2). On 12 October 2005, the diplomatic representatives of eleven predominantly Muslim countries sent a letter to Prime Minister Rasmussen. The letter mentioned the Jyllands-Posten cartoons as only the most recent and egregious example of 'an on-going smearing campaign in Danish public circles and media against Islam and Muslims'. (The letter is quoted in full in Klausen (2009, 36-37).) The representatives saw the cartoons and similar expressions as contrary to values of tolerance and human rights and warned that they could cause adverse reactions in Muslim countries and among Muslims in Europe. The representatives urged the Prime Minister to 'take all those responsible to task under law of the land' (sic). They further requested an urgent meeting and asked for an early response. Shortly after the letter from the ambassadors, the Organization of the Islamic Conference (OIC) sent a similar letter (Klausen 2009, 65, 147).

Since much of the subsequent public debate focused on the need for an apology, it deserves mention that neither letter included a demand for an apology from the government (Klausen 2009, 32-33, 65). That did not prevent OIC and many predominantly Muslim countries from subsequently making the lack of an apology the justification for the boycott against Denmark that ensued in 2006.

Prime Minister Rasmussen responded to the ambassadors on 21 October 2005. His reply did not acknowledge or address the request for a meeting at all, but rather focused on the demand that he 'take all those responsible to task under law of the land':

The Danish society is based on respect for the freedom of expression, on religious tolerance and on equal standards for all religions. The freedom of expression is the very foundation of the Danish democracy. The freedom of expression has a wide scope and the Danish government has no means of influencing the press. However, Danish legislation prohibits acts or expressions of a blasphemous or discriminatory nature. The offended party may bring such acts or expressions to court, and it is for the courts to decide in individual cases. (The letter is quoted in full in Klausen 2009, 66)

Subsequently, Rasmussen on several occasions reaffirmed the claims made in the reply to the ambassadors (Klausen 2009, 148).

There are a couple of noteworthy points about Rasmussen's reply. For one thing, there are actually several inaccuracies in his depiction of the Danish legal reality. One might question or at least wish for a qualification of Rasmussen's claim that Danish society is based on 'equal standards for all religions', given the fact that Denmark has an established Church and Rasmussen himself, his Venstre party, and his government have often invoked the slogan that in Denmark there is freedom of religion but not religious equality (Lægaard 2012). Furthermore, whilst it is true that the Danish penal code at the time included both laws against blasphemy and hate speech (Lægaard 2007), ${ }^{1}$ it is actually not true that 'The offended party may bring such acts or

\footnotetext{
${ }^{1}$ The Danish blasphemy clause was abolished in 2017.
} 
expressions to court'. Both laws are about public order, and so legal cases can only be raised in relation to these laws by the public prosecutor, not by individual claimants.

The cartoons were in fact subsequently reported to the police, so the public prosecutor had to decide whether to raise charges. Ultimately, the prosecutor, it appears, engaged in a thorough investigation of the cartoons in light of the laws against hate speech and blasphemy and eventually decided that the cartoons did not seem to constitute a violation (Lægaard 2007).

Setting these inaccuracies aside, the appeal in the Prime Minister's reply is clearly and unequivocally to the value of freedom of speech. But what, more specifically, of his failure to even acknowledge the ambassadors' request for a meeting and his choice not to meet with them? In reality, the rationale could have been practical (a busy schedule), political (not wishing to be seen to be pandering to Muslim countries), and/ or ideological (based on Danish values, including not least freedom of speech). But, as reported in the Copenhagen Post, Rasmussen himself offered the following ideological basis for his choice.

This is a matter of principle. I won't meet with them because it is so crystal clear what principles Danish democracy is built upon that there is no reason to do so. (Comments from Copenhagen Post, quoted in Ammitzbøll and Vidino 2007)

In other words, if it is self-evident that Danish society is based on respect for freedom of speech, then what would be the point of meeting to explain this to the ambassadors?

In the subsequent debate, however, Rasmussen's reply was most often linked to the issue of an official apology (or lack thereof) by the government for the fact of the publication of the cartoons. The letter sent by the OIC, for example, omitted the request to 'take all those responsible to task under law of the land' (Klausen 2009, 147), suggesting a shift of emphasis away from a request for legal intervention to the need for a government apology.

In this context, Rasmussen continued to insist that the government cannot apologize for an act committed by a private newspaper, since the newspaper is independent of the government and has its freedom of speech, which means that the government neither has responsibility for the publication nor could do anything about it.

That being said Rasmussen did not ignore or downplay the seriousness of the ensuing diplomatic crisis caused by the cartoons. Nor could he: Rasmussen's own effigy was burnt in cities in several Muslim countries. And so, during the height of the crisis in February 2006, for example, The Times reported Rasmussen as saying that the cartoons furore was 'Denmark's worst international relations incident since the Second World War' (The Times 2006).

Furthermore, Rasmussen, at the time, added that he personally would not publish anything that might offend people's religious sensibilities (Klausen 2009, 148). In an interview with Al Arabiya in February 2006, Rasmussen even condemned expressions that offend religious sensibilities or demonize people on the grounds of their religion. Rasmussen accordingly distinguished sharply between defending freedom of speech in general and endorsing particular utterances protected by freedom of speech, such as the cartoons.

In what follows, we shall use the term 'Rasmussen's choice' to refer exclusively to Rasmussen's choice not to meet with the ambassadors in person to hear their views on 
the cartoons in full (or at length). ${ }^{2}$ This is separate from any other, related choices Rasmussen did make, or could have made, concerning the publication of the cartoons themselves.

\section{Cosmopolitan Democratic and Communicative Rights}

There is a possible analysis of Rasmussen's dismissal of the ambassadors' overtures that understands and locates this sort of behaviour within Denmark's potential 'complicity', along with other northern European states, in much wider patterns, forms, and structures of postcolonialism perpetrated by the West, including economic and cultural postcolonialism, not only across the world but also in some Muslim countries. For example, Mulinari et al. highlight

the manifold ways in which North-European countries have taken, and continue to take, part in (post)colonial processes. The lure of an enterprise as powerful and authoritative as the Western civilising project, attracts even those who never belonged to its centre or were its main agents. Nations, groups, and individual subjects are drawn by the promise of power to adopt the discourses, imaginaries and material benefits connected to this project. The Nordic countries see themselves as part of the Western world, drawing their values systems from the Enlightenment, and showing themselves to be willing to defend these values sometimes even more forcefully than the former colonial centres. The recent cartoon affair in Denmark and Sweden is evidence of this willingness. (Mulinari et al. 2016, 1)

The basic contention here is that, even though Denmark has no colonial past involving any Muslim countries, Rasmussen's choice must be understood in terms of a wider pattern of powerful countries and political leaders imposing Western cultural norms, in this particular case a certain sort of free speech norm, on people living in other countries including in the Muslim world. Whilst claims around postcolonialism did not figure very much in the discussions at the time - perhaps partly because of Denmark's own history - some observers did make the point that 'Muslim sensitivity about insults to Islam in Europe has a strong postcolonial context' (Cole 2006).

However, postcolonialism lies not merely in forms of cultural hegemony in which a culturally diverse world is dominated by singular aspects of Western culture. A related, but different phenomenon is the way in which political decision-making in the West often excludes the direct voices of, or communicative inputs from, people who are not citizens of Western states - many of whom are citizens of former colonies of Western states - but who are nevertheless affected by that decision-making. This is a broader argument about cosmopolitan democratic and communicative rights; it is the focus of this article.

At the heart of many versions of cosmopolitanism is a form of moral egalitarianism which emphasizes basic human characteristics shared by everyone and that

\footnotetext{
$\overline{2}$ Of course, it is conceivable that the choice was not his; that his security chief, his diary manager, or some other official ruled out such a meeting. But we shall ignore that possibility here.
} 
unequivocally rejects ways of ordering the world that are based on a hierarchy of intrinsic worth or dignity among human beings. Historically, cosmopolitanism as a political movement has campaigned against forms transnational injustice such as the slave trade, colonial exploitation, and even global poverty, which seem to be premised on ranking persons according to higher or lower intrinsic worth.

Importantly for this article, cosmopolitan political theory highlights the fact that people around the world are affected by governmental agencies, legal jurisdictions, and systems of rules located in both other countries and international organizations, over which they exert little or no control. It also embraces the fundamental principle (the all affected principle) that being affected by the exercise of formal and informal power in other countries can ground certain cosmopolitan rights or claims. In other words, certain rights or claims to democracy, equality, justice, benevolence, and so on, extend beyond state borders (Shapiro 1999, 38; Näsström 2003, 822-825; Held 2005, 246249; Gould 2006, 54; Pogge 2008, 37-38).

With respect to issues of democracy in particular, a cosmopolitan approach puts the emphasis on how accepting the all-affected principle - a principle for delimiting who should be included in democratic decision-making - can, and should, shape the way individual states are to think appropriately about the site, scope, and content of democratic rights and associated democratic decision-making rules and procedures (Held 2005, 246-249). In the words of Sofia Näsström:

In most theories of democracy one starts out from a given people, only then to discuss the scope of its decisionmaking: how far should the power of the people extend? What is the proper domain over which it has a democratic say, and what should by contrast be considered a more private concern? What is novel about the all-affected principle is that it turns the question around. It determines the scope of the people on the basis of the scope of political decision-making. For example, what is the scope of the decisions made by the Security Council? Or what is the scope of the decision by a particular nation state to cut down on environmental protection? The answer is that the people in each case are those affected by the decision in question. (Näsström 2011, 117)

At first glance, the logic of cosmopolitan theories of democracy would seem to point in the direction of granting to all people affected by the decisions of a state, even people of other countries, the same or similar democratic rights to influence the decisions, including voting rights, for example. As Robert Goodin puts it, this logic seems to suggest 'giving virtually everyone everywhere a vote on virtually everything decided anywhere' (Goodin 2007, 68). However, this is not only merely implausible but also wildly impractical. For example, the challenges of voters being well informed enough and having a sufficient marginal contribution to make voting rational that already exist at the national level would be exponentially increased if the franchise were extended to virtually everyone on the planet (Keohane 2003).

One way to soften and render more plausible the potential implications of the allaffected principle would be to place theoretical limits on the sorts of interests that can be affected in a way that might give rise to cosmopolitan democratic rights. But then, the task is to determine what the relevant interests are (Moore 2006, 35). It may be tempting at this stage to fall back on the idea that the relevant interests are simply the 
body of human rights typically recognized in international law (Gould 2006, 54; Pogge 2008, 37-38). But then, the issue becomes how such law is created and by whom. It is plausible to suppose that this task itself should not succumb to forms of postcolonialism and cultural hegemony and must be done through some sort of global democratic procedure In which case, potentially, the previous challenges are simply moved up one level.

Fortunately, there is another way to address at least some of these problems. It is to take a layered approach to democratic rights. ${ }^{3}$ The layers of a democratic rights approach starts from the premise that people, often citizens, who are directly governed by, or subjected to, a national governmental regime or system of law, have a close connection to each other and to the institutions against which they have democratic rights. This subjection and closeness give rise to a more expansive set of political rights, extending from the right to vote in elections and the right to run for office through to the right to protest and the right to petition, to the right to hold politicians to account. This subjection and closeness in turn also gives rise to demanding norms of political communication, meaning some quite stringent obligations on politicians to submit to political accountability. Arguably, there is a primary obligation on the part of public officials to make themselves available to answer the questions (an obligation to avoid stonewalling) and an obligation to respond properly to probing questions including where feasible and reasonable to give straight answers (an obligation to avoid covert question dodging).

However, there is another layer of democratic rights that occurs at the global level. Here what matters is that people around the world are affected by governmental agencies, legal jurisdictions, and systems of rules located both in other countries and in international organizations. The fact of being affected also gives rise to a set of political rights, but these rights are less expansive than at the national level and do include many of the rights mentioned above. Instead, they include such fundamental moral rights as the right to submit information, ideas, and opinions to those who have the power to take decisions that can have systematic and adverse implications for one's vital interests, and to be meaningfully heard. This right in turn gives rise to a corresponding obligation on the part of powerful institutions and the leaders of those institutions not only to not merely receive or listen to the information, ideas, and options submitted but also to meaningfully hear them, such as, if necessary, to hear them in person and in full (or at length).

These ideas are rooted in a broader tradition of deliberative approaches to theorizing about global democracy, and, of course, this tradition has much more to say than the particular sort of communicative cosmopolitan right proposed in this article. For example, some writers in this tradition put to the forefront the importance of certain deliberative virtues that cut across borders. For example, John Rawls in The Law of Peoples highlights what he calls 'the duty of civility' on the part of liberal peoples, 'requiring that they offer other peoples public reasons appropriate to the Society of Peoples for their actions' (Rawls 1999, 59). This idea has prompted a debate in the literature about what a theory of global public reasons should look like (Brown 2010; Smith 2011; Porter 2012; Williams 2017). Others underscore the value and necessity of

\footnotetext{
${ }^{3}$ Inspiration for this view comes from a similar proposal in the field of global distributive justice. See Wolff (2009).
} 
transnational discursive and deliberative arenas, a sort of transnational public sphere, partly consisting of the media and organized civil society (Dryzek 2000; Steffek 2010; Dryzek et al. 2019).

Nevertheless, one important feature we take from this tradition is the deliberative virtue of inclusiveness, meaning a disposition to uphold the principle that people should be part of the deliberative processes of decision-making which lead to decisions being formed elsewhere in the world but which nevertheless affect them. In other words, if deliberative agents are people with a right to be involved in democratic decisionmaking and associated exercises of power or at the very least are people whose deliberations are something to which that decision-making and exercises of power should be responsive, then the status of deliberative agent should be afforded to members of 'stakeholder communities', meaning all those individuals whose autonomous capacities are constrained by the results of that democratic decision-making and exercises of power (Macdonald 2008).

Another tradition we borrow from is that of cosmopolitan approaches to discourse theory, which have the potential to furnish a more comprehensive account of the sorts of virtues public discourse at the international level should have. A key feature of discourse theory is inclusiveness: that 'only those action norms are valid to which all possibly affected persons agree as participants in rational discourses' (Habermas 1996, 107).

If inclusiveness refers to who the participants can be, another virtue speaks to how the participants are to treat each other. For example, discourse agents 'should grant each other equal discursive rights, avoid overt or covert coercion, speak their minds sincerely, and let all those who could contribute to the discussion partake in it' (Gilabert 2006, 17). Moreover, 'all interlocutors must, in principle, enjoy roughly equal chances to state their views, place issues on the agenda, question the tacit and explicit assumptions of others, switch levels as needed and generally receive a fair hearing' (Fraser 2007, 20).

Nancy Fraser (2007) situates this second virtue of equality, what she calls 'parity' of discursive participation among all affected persons, within a context of global interconnectedness. Her ideal is for the powerful - a mix of national and international, public and private, powers - to be held accountable to, and to be participants in, public discussions within national and transnational public spheres and for those public discussions to exemplify parity as well as inclusiveness.

Finally, diplomatic communication theory emphasizes the ways in which contemporary diplomatic interactions are increasingly oriented around intercultural communication (Rossow 1962). Whereas once upon a time diplomacy may have been dominated by interactions between diplomats and government ministers belonging to the same Judeo Christian family of cultures, in the twentieth century, this Europeancentred diplomatic structure has given way to a more complicated and inclusive picture of cross-cultural interactions across the globe (Belay 1997). As a result, it is arguable that ' $[\mathrm{p}] \mathrm{recisely}$ and quite simply, the professional service rendered by the diplomat is the minimizing of distortion and friction in cross-cultural communications and operations' (Rossow 1962, 563).

To perform this task, the diplomat must be able to get under the skin of other cultures, to understand, learn, and interpret them in ways that can better enable him or her to reduce misunderstandings between other cultures and the political leaders he or she serves. In that sense, access to face-to-face meetings is a crucial precondition of 
diplomatic, intercultural communication. Without access to some of the more complex cognitive and noncognitive mental states exemplified in thought processes of, and subtle nuances of positions taken by, the leaders of other countries, diplomatic communication cannot serve its core purpose of helping 'to reduce unnecessary conflict and misunderstanding, and to assure that issues are at least clear and real, and not based on phantom, myth, or mismatched codes' (Rossow 1962, 575).

In the next section, we explore the sense in which Rasmussen's dismissal of the ambassadors' overtures might be understood as evidence of a failure to cultivate or displays these virtues of deliberative, discursive, and diplomatic communication (inclusiveness, equality or parity, intercultural interpretation, access).

\section{The Right to Be Heard, Even Across Borders}

We are interested instead in circumstances in which, although a government, or its leadership, has not refused an airing of an opinion among the public, it has nevertheless itself refused to hear or receive that opinion in full (or at length) and in person. By refusing direct representations on matters affecting the vital interests of people whose representatives are seeking to make representations, such as a group of ambassadors seeking to give voice to the concerns of other cultures, a government might be violating a fundamental (cosmopolitan) moral right. This is the right to submit information, ideas, and opinions to those who wield power over oneself, that is, the power to take decisions that can have systematic and adverse implications for one's vital interests, even when that decision-making power and its implications flow across borders, and to have them meaningfully heard. We consider this right because it could explain the wrongness of Rasmussen's choice by understanding the choice as having an inherently international dimension.

As we understand it, the fundamental (cosmopolitan) moral right to submit information, ideas, or opinions, and to be meaningfully heard, is related to, but not identical with, the fundamental political right to petition one's own government. The latter right, in the most abstract sense, imposes a duty on government to receive and respond to petitions made by its citizens, including a qualified duty of neutrality which prohibits a government from engaging in content and viewpoint discrimination over what information, ideas, or opinions it will receive and from whom, absent a sufficient rationale for such discrimination. For reasons of feasibility and practicality, the right tends not to extend to meeting the government in person. Instead, it can mean that if citizens collect a given number of signatures, including digitally in the case of electronic petitions (or e-petitions), the government has a duty to respond to the petition. Importantly, the moral basis for this fundamental political right partly consists in basic norms of democratic representation. A government composed of elected representatives who refuse to receive petitions from the very people they are supposed to represent arguably serves its representative function less strongly than one whose elected representatives freely accept petitions.

The fundamental political right to petition one's own government is realized in different ways and, to varying extents, in constitutional rights and human rights around the world (Krotoszynski 2012, ch 4). The English Bill of Rights of 1689, for example, provides for the rights of subjects to petition the monarch, making prosecutions for 
such petitioning illegal. The right to petition can also be found in the last clause of the First Amendment: 'Congress shall make no law [...] abridging [...] the right of the people to freely assemble and petition government for a redress of grievances'. This in turn 'stem[med] from the right to petition local assemblies in colonial America' (Higginson 1986, 142). It is also found in Article 17 of the Basic Law of the Federal Republic of Germany and in Article 44 of the Charter of Fundamental Rights of the European Union, which provide for the right to petition to the European Parliament.

Abstracting from these particular settings, we can say that if a prime minister of a country, which respects the constitutional right to petition, had refused to hear a grievance from a significant number of citizens, then the contradiction would have taken this form: refusing to hear a grievance on grounds of the special place of freedom of speech in the society but thereby violating a right that is also bound up with freedom of speech in that society, namely, the right to petition one's own government. As we have said, this right can be grounded in basic norms of representative democracy. We also think that the right to be heard, held by citizens against their own governments, implicates important questions about democratic legitimacy. Denying citizens the chance to submit information, ideas, and opinions to their own governments lessens the ability of citizens to directly influence both the broad shape of legislative agendas and the particular content of governmental decisions, which in turn can reduce the legitimacy of downstream laws and, potentially, the legitimacy of the political system as a whole. 4

Rasmussen's choice was not a decision to refuse to meet in person with a group of Danish-Muslim citizens but a decision not to meet with a group of ambassadors from other countries. Indeed, in his letter to the delegation Rasmussen writes:

I share your view that dialogue between cultures and religions needs to be based on mutual respect and understanding. There is indeed room for increasing mutual understanding between different cultures and religions.

In this regard, I have personally taken the initiative to enter into a dialogue with representatives from the Muslim communities in Denmark. (Klausen 2009, 66)

However, it is precisely for the reason that Rasmussen refused to meet with the delegation of foreign ambassadors (but not Danish-Muslims) - and in order to find an argument that can capture the original intuition about Rasmussen's choice-we revert back to the even more fundamental (cosmopolitan) moral right to submit information, ideas, and opinions to those who wield power over oneself, and to have them meaningfully heard. This right is held by individuals against governments who possess the power to make decisions that can have systematic and adverse implications for their vital interests. If someone has this fundamental moral right in relation to a particular government, then that government should make it possible for that person to submit information, ideas, and opinions to it and to meaningfully hear that information,

\footnotetext{
${ }^{4}$ Denmark is one of only a handful of European countries that do not recognize the constitutional right of citizens to directly petition the government (European Union 2015, 12). Section 54 of the Danish Constitution of 1953 only provides a limited right to petition. It states: 'Petitions may be submitted to the Folketing [parliament] only through one of its Members.' http://www.thedanishparliament.dk/Publications/My_ Constitutional_Act_with_explanations/Chapter\%205.aspx (accessed 29 June 2020).
} 
ideas, and opinions, whilst accepting reasonable constraints of feasibility and practicality.

At the level of deep values, we suggest that the fundamental moral right to be heard is linked to issues of democratic legitimacy in the case of citizens wishing to be heard, but linked instead to norms of responsible state behaviour in the case of noncitizens (or citizens of other states). Legitimacy in the domestic context is about government decisions being responsive to facts about the impact of those decisions on citizens. But government decisions can also systematically and adversely affect the vital interests of people outside the state or noncitizens. Whilst there may be differences in kind and degree here, we believe that just as legitimacy is partly a matter of the willingness of a government to listen to its citizens, so a responsible government is partly one that fulfils certain roles in the international state system including being responsive to the effects of its decisions beyond its own borders.

No doubt similar claims could be made about other agents than states - for example, transnational corporations - who also exercise power in ways that affect the vital interests of people. This might on the one hand mean that our argument also has implications for such nonstate actors. This is not necessarily an unreasonable implication, but it is beyond the present study to investigate this. On the other hand, state power is widely recognized as different from other sorts of power, which justifies our focus on states in this article; so we shall assume for the sake of argument.

At a more concrete level, the fundamental moral right to be heard can, and often should, be realized differently for citizens and noncitizens. In the context of domestic politics, the moral right to be heard is realized through the political right of citizens to petition their governments. For reasons of feasibility and practicality, the corresponding duty can be reasonably viewed as being discharged by systems of e-petitions in which any group of citizen petitioners must secure a minimum threshold of electronic signatures before the government is required to respond. But whereas the political right to petition is a bounded right for citizens, the moral right to be heard creates an unbounded duty in the case of noncitizens in international contexts. Nevertheless, once again for reasons of feasibility and practicality, in the case of noncitizens the moral right to be heard might be realized through the institution of international diplomacy.

We propose that in the case of the Muslim ambassadors and, more importantly, those they represented, the fundamental (cosmopolitan) moral right to be meaningfully heard created a cosmopolitan moral duty on the part of Rasmussen, as the senior representative of the Danish government, to meet with the ambassadors.

Of course, the idea of a right to submit information, ideas, and opinions to those who hold 'power' over those doing the submitting is more complex in the Rasmussen case for two reasons: first, he does not have unilateral authority to interpret the Danish constitution or even to launch criminal proceedings, and, second, because, at first glance, it may not be obvious what coercive power or even informal influence the Danish government might have over citizens of other states in relation to the Danish cartoons affair. However, as we shall explain and defend below, we believe that Rasmussen did, indeed, have both power and influence in ways that sufficed to trigger the moral rights and obligations we are proposing.

In other words, in order to provide an argument why Rasmussen's choice was morally problematic, we suggest that one needs to appeal to a cosmopolitan right, which creates, in certain contexts, a cosmopolitan duty. This is a cosmopolitan duty in 
the sense that it embodies the core notion that individuals whose vital interests are systematically and adversely affected by the actions of governments are entitled to have their interests taken into consideration in some appropriate way irrespective of what national affiliation they have, even if those governments do not have political authority over the individuals concerned and even if those individuals have no obligation to obey the laws and rules promulgated by those governments, such as individuals living in other countries.

We assume the cosmopolitan duty to have special force or applicability to those in positions of political power. This is so not merely because they hold a monopoly on the exercise of at least some forms of coercive power but also because they can have a special kind of informal power including particular forms of status, authority, and influence (Brown and Sinclair 2020, ch 7). We do not have space here to discuss whether the same cosmopolitan duty might also be applicable to those in positions of economic or social power. One potential difference may be that although private actors like major newspapers or social media companies, say, are also often powerful, they are usually one among several actors in a market, or voices in civil society, and as such, they do not have exactly the same sort of singular or focal authority or influence of a political leader - an individual who can speak on behalf of, or is perceived to be able to speak on behalf of, the state or even the nation, for example.

The failure of Rasmussen to meet with the ambassadors in person to receive their concerns and perspectives in full (or at length) therefore partially violated their fundamental (cosmopolitan) moral right to submit information, ideas, and opinions to him and to be meaningfully heard. (A partial violation because he did hear their grievance, by reading the letters submitted to him, and he did provide one means of submitting information to him, by receiving the letters submitted to him.)

This violation may not directly implicate domestic issues of democratic legitimacy or representative democracy or other fundamental norms relating to domestic political affairs. However, arguably, this violation does raise questions about what it means to be a good member of the community of states. A responsible state, or the government of a responsible nation, is arguably one that respects the aforementioned fundamental moral right. This is because the fundamental moral right to be heard can, and often does, create cross-border duties. Since foreign citizens have no vote in how a state makes internal decisions, ambassadors are the primary mechanism of representation. There is therefore something particularly perverse about failing to meet with ambassadors, given their crucial role in representing the interests of nonstate citizens.

Of course, whilst some people might be willing to entertain the idea that the Danish government's handling of the case of the cartoons did raise issues that could have adversely affected the vital interests of Muslims in other countries, as well as in Denmark, such as interests relating to the protection of their civic dignity or cultural identity (Waldron 2010; Brown 2015, chs 5 and 6), clearly other people might reject this idea out of hand. They might say that the cartoons merely hurt religious sensibilities and that this hurt is not a matter of vital interests. However, we believe that, even, or perhaps especially, in cases where there is reasonable disagreement about whether vital interests have been adversely affected, it is important to allow people who in good faith assert that their vital interests have been adversely affected to have a voice and to listen to why they think this to be the case.

One objection to our proposal might be that even elected representatives have a right not to receive certain kinds of information, ideas, or opinions. According to the values 
of militant democracy, for instance (Loewenstein 1937a, 1937b), freedom of speech matters for reasons of democracy, but sometimes in order to defend democracy against existential threats, it is justifiable to neutralize those threats by limiting, or refusing to countenance, anti-democratic speech. Suppose a prominent politician believes that a certain group of citizens would want to engage in anti-democratic speech when they met with him or her-for example, speech defending unjustifiable limits to freedom of speech. According to the current objection, the prima facie duty of elected representatives to receive information, ideas, or opinions does not extend to receiving information, ideas, or opinions that are themselves anti-democratic.

However, it is not clear what should count as anti-democratic speech here. Suppose the citizens are Muslims who wish to defend limiting freedom of speech when it comes to group libels targeting religious believers. In theory, the argument from militant democracy could also be deployed by these citizens as a justification for their calling on politicians to introduce laws banning group libels targeting religious believers or to further clarify the existing laws so that they cover cartoons depicting all Muslims as terrorists, for example (Brown 2015, 194-201). Perhaps such cartoons could be viewed as, directly, an attack on the reputation and equal standing of all Muslims and, indirectly, contributing to a climate of Islamophobia that carries a clear and present threat to fair and effective access to public discourse, and even to processes of democratic decision-making, on the part of Muslims.

Another objection might be that the fundamental moral right to be heard seems overbroad, for the simple reason that it gives people communicative rights over almost any powerful government, whether or not it is their own. So, for example, the fundamental moral right to be heard seems to imply that all, or nearly all, Mexicans have a right to submit information, ideas, and opinions to the US government over its plans to build a wall between the two countries.

However, our response is that both the fundamental moral right to be heard and the duties it creates are qualified by reasonable constraints of feasibility and practicality. Thus, in the case of noncitizens, the moral right to be heard can be understood as the right of Mexicans to have their representatives make diplomatic representations to foreign governments - for example, representations about US immigration policy made by the Ambassador of Mexico to the US on behalf of Mexicans, in general. This means that the rights of ambassadors are derivative of the fundamental moral cosmopolitan rights of the people they represent. So according to this way of understanding what was problematic about Rasmussen's choice, it wronged the peoples of these countries and only the ambassadors derivatively.

Another worry might be that the ambassadors did not in fact hold a right to be heard by Rasmussen, concerning this matter, because he did not publish the cartoons. The point is that even if one accepts for the sake of argument that the publication of the cartoons had an adverse impact on the vital interests of individuals living in the eleven predominantly Muslim countries whose ambassadors requested a meeting with Rasmussen, ${ }^{5}$ such as because the cartoons caused reputational damage to, or constituted a form of misrecognition of, these Muslims, and even if one accepts that when the ambassadors came forward they were acting in the name of or had been delegated to speak for the interests of, these Muslims, the substantive issue remains whether they

\footnotetext{
$\overline{5}$ It should also be noted that many resident Muslims in Denmark remain citizens of these countries.
} 
had a moral right to submit information, ideas, and opinions to Rasmussen, in addition to the Danish newspaper involved.

In our view, this substantive issue depends not only on whether he wielded power to take decisions that could have removed, mitigated, or lessened the relevant adverse impact on their vital interests but also on whether there was reasonable disagreement about whether Rasmussen held certain power. Moreover, even if Rasmussen was right to say that he simply did not have the power to 'take all those responsible to task under law of the land', this in itself does not foreclose the possibility that there were other actions that Rasmussen did have the power to take. For example, he clearly had the power to counter-speak against the cartoons, to publicly denounce them as biased characterisations of the Prophet Muhammad and by association unfair generalizations about Muslims in general. These statements could have improved or helped the vital interests of Muslims both in Denmark and around the world - in relation to reducing and mitigating forms of anti-Muslim discrimination, hostility, and cultural imperialism, for example.

Alternatively, he could have simply made clear publicly that even though the government was not responsible for the cartoons and he could not do anything about them, he would not personally have published such cartoons and would not endorse the cartoons. Perhaps had Rasmussen agreed to meet with the ambassadors - to make it plain to them what he did not have the power to do-they would have then made another request, namely, that he counter-speak against the cartoons or at the very least make it clear that he would not endorse them.

Interestingly, back in October 2005, some of the ambassadors who had sent the original letter were also publicly calling for Rasmussen to at least distance the state from the cartoons and to reaffirm the incompatibility between the cartoons and Denmark's respect for Muslims. For example, Egypt's Ambassador, Mona Omar Attiah, is reported to have publicly stated the following on 27 October 2005:

It is a big misunderstanding when people think we have asked the Prime Minister to put limits on freedom of speech. We wished for him to call for a responsible and respectful use of this freedom. We also wished for him to take a moral position by declaring that Danish society is striving for the integration, not the demeaning, of Islam. (Comments quoted in Engelbreth Larsen 2010).

In this context, we also note that, within scholarly debates on hate speech, several thinkers have argued that institutional authorities can, and should, play an active part as counter-speakers against hate speech without becoming censors of hate speech or advocating the censorship of hate speech (Strossen 1990, 562; 2001, 272; 2012, 387-388, 392; Gelber 2002, 2012; Brettschneider 2013, 642; Lepoutre 2017).

Nevertheless, at this stage, it might be objected that Rasmussen's letter of reply to the ambassadors counted as engagement with their views. In other words, simply by reading the ambassadors' letter and replying to it he respected their moral right to be heard. We think that there is an element of truth in this objection but that it is not decisive. In fact, the ambassadors' letter was partly a request for Rasmussen to take action and partly a request for a meeting to enable the ambassadors to express their views to him in full and in person. Rasmussen's letter of reply dealt with the former, but not the latter, since he did not, and could not, have anticipated what those views would 
be. As such, we believe that at best, Rasmussen only partially respected the ambassadors' moral right to be heard by writing the letter of reply he did.

Now the objector might insist that, even if one accepts that the ambassadors had a right to submit a lengthier set of ideas or arguments to Rasmussen than were contained in their original, brief letter, this did not create a duty on the part of Rasmussen to meet with them in person, in the way the ambassadors requested. Perhaps their right to be heard would have been met, given constraints of feasibility and practicality, by their submitting a longer written statement and by Rasmussen responding to that statement with an official reply.

We accept this line of reasoning, up to a point. If, at the time, Rasmussen had set forth a pressing practical reason for not meeting the ambassadors in person, but, in addition, had offered to receive and respond to a longer written statement from them, then this would have upheld their rights, we believe. However, Rasmussen set forth no such reason and made no such offer. In fact, Rasmussen's publicly stated reason for refusing to meet the ambassadors in person to hear their concerns in full (or at length) was that there was no point, because the substantive debate was settled. This, we argue expressed disregard for the moral right to be heard of the ambassadors, and of all those Muslims they represented. By both refusing to meet with the ambassadors in person and failing to offer to receive their full ideas and arguments in some other way, Rasmussen demonstrated an unwillingness to engage with them at all. This unwillingness, along with Rasmussen's stated reason for not meeting, showed that he did not adequately respect their right to be heard.

To be clear, we have not here attempted to provide a full specification of what the right to submit information consists in, which would include specification of the full range of correlative moral duties, and of mitigating practical considerations that might outweigh such duties or excuse the failure to act on them under certain circumstances. A comprehensive theory would have to address such issues.

Importantly, a comprehensive theory would also need to consider potentially countervailing moral duties of a pressing or urgent kind that might trump the obligation to meaningfully hear information, ideas, and opinions from affected persons. For example, the obligation to meaningfully hear might be superseded or overpowered by an obligation not to give a platform to encourage or otherwise recognize and support the political agenda of people who egregiously reject liberal democratic norms (i.e. where there is little or no room for reasonable disagreement). This is unlike the political agenda of the ambassadors from Muslim countries, which either support or acknowledge the right to freedom of expression in more qualified ways and which are not necessarily entirely illiberal in their approach to free speech (and where there is plenty of room for reasonable disagreement).

Suppose, for instance, Rasmussen had refused to meet a delegation of Danish citizens who support violent far right politics - or even a delegation of ambassadors from countries with violent far right governments - who wanted to call on the Prime Minister to strip all Danish Muslims of their citizenship, to use violent anti-protest tactics and detention without trial against Muslim protestors in Denmark and even to impose economic sanctions on, boycott all trade with, and, if necessary, bomb, Muslim countries involved in the international protests against the Danish cartoons. In such a case, Rasmussen's obligation to send an expressive or symbolic message of liberal 
values and intercultural peace and tolerance, communicated by his refusal to meet these delegations, would supersede any obligation to meet them.

Indeed, the delegations in this hypothetical case may have significantly less political legitimacy and moral authority to speak for, or represent, 'the people' than the Muslim ambassadors in the Danish cartoons affair. Consequently, an obligation to meaningfully hear them may not be triggered in the first instance.

However, to repeat, our aim has not been to offer a full theory of rights and obligations but to suggest that something like the fundamental (cosmopolitan) moral right to be meaningfully heard is needed to account for the initial intuition about Rasmussen's choice.

\section{Recent Developments and Implications}

We have argued that Rasmussen's unwillingness to discursively engage with the ambassadors - to receive their ideas and perspectives in person and in full (or at length) - and for the reason he provided, constituted a partial violation of a fundamental (cosmopolitan) moral right to be meaningfully heard on the part of those millions of Muslims the ambassadors sought to represent. In grounding moral criticism of Rasmussen's choice in this way, we are not claiming that Rasmussen was guilty of subverting freedom of speech-for example, he did not explicitly call on others to refuse to meet the ambassadors, and he did not attempt to censor or expel the ambassadors. Nor are we claiming a crude moral equivalence between refusing to meet with the ambassadors and censoring the ambassadors.

In this final section, we trace some recent developments in the Danish cartoons controversy and address some implications. First, we note that Rasmussen's refusal to meet with the ambassadors was at the time accompanied with calls for more 'dialogue' with Muslims, as exemplified with the government's own diplomatic initiative 'Partnership for Progress and Reform' directed at the Arab world. We would argue that such initiatives much better reflect what it would mean to respect the right to be heard on the part of Muslims in the wake of the Danish cartoons controversy.

Second, when Rasmussen originally refused to meet with the ambassadors, and declined to offer an official apology for the cartoons, part of his justification was that he was defending the importance of freedom of speech in general, but at the same time, he, and his government, was not endorsing any specific utterances or expressions, such as the cartoons, protected by it. Indeed, in 2009, Rasmussen took up the post of Nato secretary general and whilst still refusing to apologize for the cartoons-despite pressure from Turkey to do so- he did say, 'I was deeply distressed that the cartoons were seen by many Muslims as an attempt by Denmark to mark and insult or behave disrespectfully toward Islam or the Prophet Mohammad' (Butler and Yackley 2009).

The Danish government's attempt to draw a line between upholding free speech whilst not endorsing the symbolism of the cartoons has subsequently been challenged, however. In September 2017, Inger Støjberg, then minister for immigration and integration in the Danish government also led by Rasmussen's former party (the liberal party), published the most controversial of the Jyllands-Posten cartoons on her Facebook page. Her justification accompanying the picture was that she loved the foundation of liberty rights, including most prominently freedom of expression, on 
which Danish society is based. She also added, 'we should be proud of the Mohammad cartoons' (The Independent 2017). Støjberg thereby went directly against Rasmussen's original line of argument, according to which the publication had nothing to do with the government and did not reflect his or the government's own view. Støjberg instead makes the cartoons her own by actively republishing the most controversial one of them herself, and endorsing them by saying that Danes should be proud of them. This development is perhaps even more regrettable than Rasmussen's choice. It is arguable that those in positions of power, especially the government, have a responsibility to avoid (unwittingly) sending out messages that certain opinions are simply not worthy of public debate. Not only do Støjberg's statements dissolve the distinction between defending freedom of speech and actually endorsing the cartoons - a distinction that may have somewhat mitigated the problematic nature of Rasmussen's choice - but they also send out a message that potentially damages values of civic dignity and cultural recognition, not least the equal standing of Muslims in Danish society (Brown 2015, chs 5 and 6).

Third, it is important to see the unfolding international controversy surrounding the cartoons as part of a much wider discussion about the human right to freedom of expression and how that right might be qualified under international law. For example, some Muslim states, like Turkey, extend the meaning of hate speech to include not merely defamation of Muslims but defamation of the Muslim religion (Brown and Sinclair 2020, 79-81). Moreover, at the international level, with the backing of the OIC, the UN Commission on Human Rights (UNCHR) introduced the first resolution on defamation of religions back in 1999, and similar resolutions were made periodically over the following decade (ibid, 172). However, the USA, especially under the Obama administration, has worked hard to reassert within international law a firm distinction between anti-Muslim hate speech and speech (or cartoons) that constitute defamation of the Muslim religion (ibid, 172-174, 194-195). In this way, Rasmussen was anticipating, to some extent, shifts in international law that would come later.

Fourth, in Rasmussen's subsequent interviews on Al Arabiya and similar appearances, he came very close to issuing an apology in the interest of easing the international pressure on Denmark. He evidently gave one impression of his views when facing a domestic audience and another when trying to do international damage control. On one possible reading, this is an example of a statesperson operating, even if implicitly, a sort of calculus balancing a cultural commitment to promoting and defending free speech norms, on the one hand, and against other considerations and values such as international peace and stability, on the other hand. But what is still missing is the recognition of the importance of cosmopolitan deliberative and communicative considerations and the obligation to receive information, ideas and arguments from persons affected by one's decisions, even if they live in other parts of the world.

Fifth, it deserves mention that even if Rasmussen had agreed to meet with the ambassadors, and thereby made a different choice, arguably, he would have been confronted with another, no less difficult freedom of speech dilemma: namely, whether or not to release details about the discussion to the public. On the one hand, this would have created (on one possible reading of the situation) an opportunity for Danish citizens to observe a collision of truth with error and, therefore, an opportunity for them to acquire a clearer perception and livelier impression of truth. On the other hand, it is not clear that had a meeting taken place between Rasmussen and the ambassadors it 
would have been normal or agreeable for the sides to release a recording or transcript of the meeting to the public. Successful (as opposed to unsuccessful) diplomacy typically goes on behind closed doors: the diplomatic practice or convention of keeping some sensitive conversations out of the public domain can serve the political interests of all concerned. And so, in the interests of the art of diplomacy perhaps the only realistic choice before Rasmussen, from his own political perspective, was whether to meet the ambassadors in private or not to meet them at all.

Finally, we have said that international diplomacy often happens behind closed doors and for good reasons. But does this create a problem for the idea that ambassadors are the appropriate agents to represent people from other countries so as to ensure that their fundamental moral right to be heard is respected. Some people might assume that in order for that right to be properly respected, a condition of publicity must be satisfied: people must have knowledge of the way in which their information, ideas, and opinions have been interpreted, presented, and defended by their representatives. If so, then the secrecy of diplomacy potentially makes ambassadors inappropriate representatives, such that we might need to think of other ways for the voices of noncitizens to be heard.

However, we would argue that it is perfectly possible for ambassadors to meet the demands of publicity when speaking to those they represent, whilst at the same time conducting diplomacy itself behind closed doors. The twin purposes can be served, we believe, through the convention of diplomats, on the one hand, giving interviews to the media prior to holding international talks, and then holding press conferences, and sometimes even joint press conferences, after the talks, in which they issue a common statement about what was discussed and answer a few questions from the press about the same, ${ }^{6}$ but, on the other hand, holding the talks themselves in private and not releasing recordings or transcripts of those meetings.

Open Access This article is licensed under a Creative Commons Attribution 4.0 International License, which permits use, sharing, adaptation, distribution and reproduction in any medium or format, as long as you give appropriate credit to the original author(s) and the source, provide a link to the Creative Commons licence, and indicate if changes were made. The images or other third party material in this article are included in the article's Creative Commons licence, unless indicated otherwise in a credit line to the material. If material is not included in the article's Creative Commons licence and your intended use is not permitted by statutory regulation or exceeds the permitted use, you will need to obtain permission directly from the copyright holder. To view a copy of this licence, visit http://creativecommons.org/licenses/by/4.0/.

\section{References}

Ammitzbøll P and Vidino L (2007) After the Danish cartoon controversy. Middle East Quarterly 14: 3-11. http://www.meforum.org/1437/after-the-danish-cartoon-controversy (accessed 26 June 2020).

Belay G (1997) Ethics in international interaction: perspectives on diplomacy and negotiation. In: Casmir FL (ed.) Ethics in intercultural and international communication. Mahwah, NJ: Lawrence Erlbaum.

\footnotetext{
${ }^{6}$ Joint press conferences require that the parties have reached sufficient agreement to enable a joint statement, which is not always the case. Interestingly, an example of disagreement played out during the Danish cartoons controversy, when the then Turkish Prime Minister, Recep Tayyip Erdoğan, visited Copenhagen and refused to appear together with Rasmussen after their meeting on the grounds that Rasmussen had not banned a Kurdish television station from operating from Copenhagen.
} 
Brettschneider C (2013) Value democracy as the basis for viewpoint neutrality: A theory of free speech and its implications for the state speech and limited public forum doctrines. Northwestern University Law Review 107: 603-645.

Brown A (2010) On the public reason of the society of peoples. Public Reason 2: 43-60.

Brown A (2015) Hate speech law: a philosophical examination. New York: Routledge.

Brown A and Sinclair A (2020) The politics of hate speech laws. London: Routledge.

Butler D and Yackley AJ (2009) New NATO chief pledges conciliation with Muslims, Reuters, 6 April. https:/www.reuters.com/article/us-nato-rasmussen/new-nato-chief-pledges-conciliation-with-muslimsidUSTRE5351GU20090406 (accessed 26 June 2020).

Cole J (2006) All cartoon politics are local. The Salon, 9 February. Available at: https://www.salon.com/2006 /02/09/culture 3/ (accessed 29 June 2020).

Dryzek J (2000) Deliberative democracy and beyond: liberals, critics, contestations. Oxford: Oxford University Press.

Dryzek JS et al. (2019) Deliberative global governance. Cambridge: Cambridge University Press.

Engelbreth Larsen R (2010) The Danish cartoon affair. Counterpunch, 24 September. Available at: https://www.counterpunch.org/2010/09/24/the-danish-cartoon-affair/ (accessed 30 June 2020).

European Union, Directorate-General for Internal Policies (2015) The right to petition. European Union, Brussels. http://www.europarl.europa.eu/RegData/etudes/STUD/2015/519223/IPOL STU(2015 )519223 EN.pdf (accessed 26 June 2020).

Fraser N (2007) Transnationalizing the public sphere: on the legitimacy and efficacy of public opinion in a post-Westphalian world. Theory, Culture and Society 24: 7-30.

Gelber K (2002) Speaking back: The free speech versus hate speech debate. Amsterdam: John Benjamins Publishing.

Gelber K (2012) "Speaking back": The likely fate of hate speech policy in the United States and Australia. In Maitra I and McGowan M (eds.) Speech and harm: controversies over free speech. Oxford University Press, Oxford.

Gilabert P (2006) Cosmopolitanism and discourse ethics: a critical survey. New Political Science 28: 1-21.

Goodin R (2007) Enfranchising all-affected interests, and its alternatives. Philosophy and Public Affairs 35: $40-68$.

Gould C (2006) Self-determination beyond sovereignty: relating transnational democracy to local autonomy. Journal of Social Philosophy 37: 44-60.

Habermas J (1996) Between facts and norms, W. Regh (trans.). Cambridge MA: Polity Press.

Held D (2005) Democratic accountability and political effectiveness from a cosmopolitan perspective. In: Held D and Koenig-Archibugi M (eds.) Global governance and public accountability. Oxford: Blackwell Publishing.

Higginson SA (1986) A short history of the right to petition government for the redress of grievances. Yale Law Journal 96: 142-166.

Independent The (2017) Denmark's immigration minister uses cartoon of Prophet Mohammad as iPad background. The Independent, 26 September. http://www.independent.co. uk/news/world/europe/denmark-immigration-minister-prophet-mohammad-ipad-background-ingerstojberg-a7968121.html (accessed 26 June 2020).

Keohane R (2003) Global governance and democratic accountability. In: Held D and Koenig-Archibugi M (eds.) Taming globalization: frontiers of governance. Cambridge MA: Polity Press.

Klausen J (2009) The cartoons that shook the world. New Haven, CT: Yale University Press.

Krotoszynski RJ (2012) Reclaiming the petition clause: seditious libel, "offensive" protest, and the right to petition the government for a redress of grievances. New Haven, CT: Yale University Press.

Lægaard S (2007) The cartoon controversy: offence, identity, oppression? Political Studies 55: 481-498.

Lægaard S (2012) Unequal recognition, misrecognition and injustice: the case of religious minorities in Denmark. Ethnicities 12: 197-214.

Lægaard S (2013) Danish anti-multiculturalism? the significance of the political framing of diversity. In: Kivisto P and Wahlbeck Ö (eds.) Debating multiculturalism in the Nordic welfare states. Basingstoke: Palgrave Macmillan.

Lepoutre M (2017) Hate speech in public discourse: A pessimistic defense of counterspeech. Social Theory and Practice 43: 851-883.

Loewenstein K (1937a) Militant democracy and fundamental rights I. American Political Science Review 31: 417-432.

Loewenstein K (1937b) Militant democracy and fundamental rights II. American Political Science Review 31: 638-658. 
Macdonald T (2008) Global stakeholder democracy: power and representation beyond liberal states. Oxford: Oxford University Press.

Moore M (2006) Globalization and democratization: institutional design for global institutions. Journal of Social Philosophy 37: 21-43.

Mulinari D et al. (2016) Introduction: postcolonialism and the Nordic models of welfare and gender. In: Keskinen S et al. (eds.) Complying with colonialism: gender, race and ethnicity in the Nordic region. London: Routledge.

Näsström S (2003) What globalization overshadows. Political Theory 31: 808-834.

Näsström S (2011) The challenge of the all-affected principle. Political Studies 59: 116-134.

Pogge T (2008) World poverty and human rights, second edition. Cambridge: Cambridge University Press.

Porter T (2012) Rawls, Reasonableness, and International Toleration. Politics, Philosophy, and Economics 11: 382-414.

Rawls J (1999) The law of peoples. Cambridge, MA: Harvard University Press.

Rose F (2005) Muhammeds ansigt ['The Face of Mohammad'] Jyllands-Posten, 30 September (Kulturweekend, 3).

Rossow R (1962) The professionalization of the new diplomacy. World Politics 14: 561-575.

Shapiro I (1999) Democratic justice. New Haven CT: Yale University Press.

Smith W (2011) Deliberation beyond borders: the public reason of a society of peoples. Journal of International Political Theory 7: 117-139.

Steffek J (2010) Public accountability and the public sphere of international governance. Ethics and International Affairs 24: 45-67.

Strossen N (1990) Regulating racist speech on campus: a modest proposal. Duke Law Journal 1990: 484-573.

Strossen N (2001) Incitement to hatred: should there be a limit? Southern Illinois University Law Journal 25: 243-279.

Strossen N (2012) Interview. In: Herz M and Molnar P (eds) The content and context of hate speech: Rethinking regulation and responses. Cambridge University Press, Cambridge.

Times The (2006) 70,000 Gather for violent Pakistan cartoons protest. The Time, 15 February. Available at: http://www.pakpassion.net/ppforum/archive/index.php/t-18227.html (accessed 29 June 2020).

Waldron J (2010) Dignity and defamation: The visibility of hate. Harvard Law Review 123: 1596-657.

Williams J (2017) War and global public reason. Utilitas 29: 398-422.

Wolff J (2009) Global justice and norms of co-operation: the "layers of justice" view. In: de Wijze S et al. (eds.) Hillel Steiner and the anatomy of justice: themes and challenges. London: Routledge.

Publisher's Note Springer Nature remains neutral with regard to jurisdictional claims in published maps and institutional affiliations. 